\title{
Talking war and peace at pre-summit Stanford meeting
}

\section{Palo Alto}

ThE arrival of the Soviet leader, $\mathrm{Mr}$ Mikhail Gorbachev, in Washington this week was happily timed for Stanford University's Center for International Security and Arms Control. A longplanned conference on arms control, falling by chance on the last weekend before the summit, benefited from the participation of two of Gorbachev's scientific advisers. Their presence - by videolink from Washington - made up to some extent for the failure of Andrei Sakharov to win permission to attend.

The Soviet participants, academicians Yevgenii Primakov and Yevgenii Velikhov, did not lack openness; Primakov brought up the troubles in Afghanistan, suggesting that US speakers might have avoided the topic out of politeness. The view of arms policy they brought with them reinforced the views expressed earlier by Stockholm Peace Research Institute director Walter Stuetzle that Western leaders seem not to have gained "intellectual parity" with Gorbachev.

The Soviet Union, Velikhov said, "is not interested in a less secure United States, because a less secure United States is more aggressive and the situation more tense". The old Geneva negotiating style of "trading warheads", to win a concession from the other party, is "wrong". A new approach is needed, he said, in which the goal is "better stability".

That view is not one that has been much apparent in arms negotiations. SALT II, the last major US-Soviet arms agreement, Velikhov said, was in "fundamental error". Many of his Western colleagues would agree. By placing limits on launcher categories, rather than on warhead numbers, the treaty encouraged both the United States and the Soviet Union to put highly accurate warheads on their missiles.

The resulting nuclear force is of the worst kind, capable of carrying out an overwhelming first strike against military targets with its huge number of warheads $(4,000$ on Soviet SS 18 s and 19 s, 2,650 on US Minuteman IIIs and the MXs now being deployed) while so vulnerable that launch on first warning of attack is encouraged. This force, Velikhov said, contrasts with the more stable deterrence of the submarine fleet, where communications difficulties and lesser missile accuracy give poor potential for coordinated surprise attacks, while the fleet's invulnerability ensures that attackers cannot escape retaliation.

Putting the United States and the Soviet Union back into a stable nuclear configuration will not be easy. The Soviets have far more strength tied up in massive land- based missiles and pressure for change will be felt to fall unfairly upon them. Nevertheless, Velikhov said that the hoped-for agreement to cut nuclear forces by 50 per cent could be reached by "next spring". As cuts go deeper than that, the problems posed by Strategic Defense Initiative (SDI) would increase, he said. Any kind of deployed defence system would hit at the underlying philosophy of maintaining forces that are too small for a pre-emptive strike, but sufficiently invulnerable to ensure retaliation.

Velikhov also presented results from the collaboration between the Academy of Sciences of the USSR and the National Resource Defense Council (see Nature 328, 192; 1987), which took a team of US seismologists to the Soviet Union. The problem of verification of a test-ban treaty is "solved" he said. Monitoring of a nonnuclear test explosion at distances of 250 and $600 \mathrm{~km}$ from the Semipalatinsk test site showed that an explosion could neither be hidden in natural earthquake tremors nor decoupled from the surrounding rock.

Alun Anderson

\section{Superconductors by new melt process}

Washington

A SUPERCONDUCTING yttrium-barium-copper oxide compound that retains its critical current density in a strong magnetic field has been developed at AT\&T Bell Laboratories.

Using a technique called melt-textured growth, Sungho Jin, Thomas Tiefel, Richard Sherwood and Bruce van Dover created a sample that had a critical current density of 7,400 amps per $\mathrm{cm}^{2}$ at zero magnetic field, and 1,000 amps per $\mathrm{cm}^{2}$ in a 1-tesla magnetic field at $77 \mathrm{~K}$

In the new process, powders of yttrium, barium and copper oxides in a 1:2:3 ratio are heated

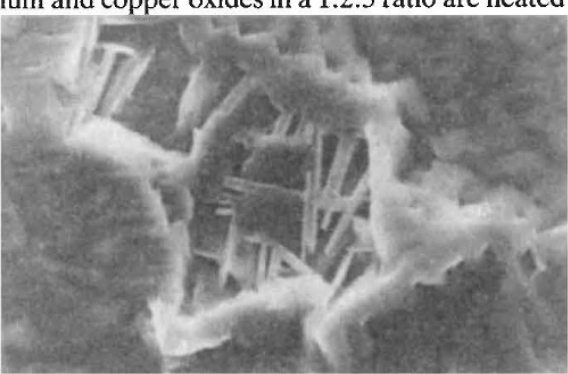

An electron micrograph of the 'needle-like' structures that result from melt-textured growth. to $1,300^{\circ} \mathrm{C}$, past their melting points, then cooled rapidly. The resulting compound is then annealed. The morphology of the melt-textured growth micro-crystals is decidedly different from those formed by sintering where the rareearth powders are kept below their melting points. The results were presented last week at the Materials Research Society meeting in Boston. Joseph Palca

\section{Conference acts on arms control policy education}

\author{
Palo Alto
}

THIS week's conference at Stantord was part of the continuing effort of the Center for International Security and Arms Control to educate the public, and scientists in particular, in the issues of arms control policy. Two physicists, Wolfgang Panofsky and Sidney Drell, now respectively directoremeritus and deputy director of the Stanford Linear Acclerator Center, set up the centre fifteen years ago together with political scientist John Lewis.

All remain active in the centre's affairs, Drell and Lewis as co-directors, and have seen it grow to the largest arms control study centre in the United States. Its 70 members are much in demand as advisers.

Drell, now 61, says he "keeps getting pulled back to his physics" but retains a particular interest in running the centre's science fellowship scheme. This provides three fellowships a year to train mid-career scientists in arms control issues.

The aim is to ensure that there is a new generation of scientists, competent both scientifically and politically, who can succeed such earlier leaders as Hans Bethe, Charles Townes and Richard Garwin. Drell also runs a weekly seminar on technical issues in arms control.

The quality of scientific advice received by the administration and the responsibility of scientists to speak accurately on technical issues much exercise Drell. He regrets the lack of authoritative advice at the White House since the abolition of the President's Scientific Advisory Committee in 1973. During the present administration, Drell says, the signs are that there has been little scientific advice on defence issues. Drell notes that Nobel-prizewinning physicist John Bardeen, although then a member of the White House Science Council, was not consulted before President Ronald Reagan suddenly launched the SDI in March 1983.

But President Reagan is taking at least some advice from Stanford. Just down the road from Drell's office is the Hoover Institution and Edward Teller, who has much encouraged the president's faith in SDI. Indeed, as the arms control conference opened in Washington, Teller was in the news again with enthusiastic support for an early deployment of missile defences.

Drell backs the view that research on SDI should continue but that deployment must be restricted by the conventional interpretation of the ABM treaty. Which view is to prevail is likely to be a critical issue at this week's summit.

Alun Anderson 